\title{
Complex aortaaneurysmák kezelési lehetőségei - saját tapasztalatok
}

\section{Treatment options for complex aortic aneurysms - own experiences}

\author{
DZSINICH CSABA ${ }^{1, @}$, SZENTPÉTERY LÁSZLÓ², NAGY GABRIELLA ${ }^{3}$, PATAKI TIBOR $^{3}$, \\ DARABOS GÁBOR ${ }^{1}$, BARTA LÁSZLÓ ${ }^{1}$ \\ ${ }^{1}$ HM Egészségügyi Központ Szív-Ér-Mellkas Sebészeti Osztály (mb. osztályvezető: dr. Darabos Gábor) \\ ${ }^{2}$ Intervenciós Radiológiai részleg (vezető: dr. Szentpétery László) \\ ${ }^{3}$ Anaestheziológiai és Intenzív Therapiás Osztály (osztályvezető: dr. Csomós Ákos)
}

\begin{abstract}
Complex aortaaneurysmáról beszélünk, ha az több, egymástól anatómiailag nem elválasztható aortaszegmentumra terjed, és/vagy az aneurysma egy vagy több életfontosságú mellékág szájadékát is magában foglalja. Kettős vagy többszörös aortaaneurysmák egymástól sebészileg jól szeparálható elváltozásokat jelentenek. Míg a complex elváltozások egy ülésben vagy időben, egymást néhány nappal követő beavatkozással kezelendők, addig a kettős/többszörös aneurysmák szeparált megoldásokkal uralhatók. E kiterjedt elváltozások kezelése jelentős javallati és technikai kihívásokkal társul. A kezelési lehetőségek széles spektrumával rendelkezünk. Korábban a nagy sebészi traumával, jelentős morbiditással és mortalitással járó nyitott mütétek nagy rizikóval terhelt betegeken siker reményében nem voltak elvégezhetők. Napjainkban a sebészi és endograft technikákkal végzett hybrid mütétek, illetve a tisztán endovascularis megoldások a kiterjedt elváltozások kezelésének javallatát jelentősen kiszélesítették. Dolgozatunkban ismertetjük a lehetséges, és az általunk már alkalmazott technikákat, valamint azokat a lehetőségeket, amelyeket a rohamos technikai fejlődés kínál.
\end{abstract}

Kulcsszavak: complex aortaaneurysmák, nyitott sebészet, hybrid megoldások, endovascularis technikák

Complex aortic aneurysms extend to more aortic segments, and/or include one or more orifices of highly important side branches. Meanwhile complex aneurysms need reconstructive solutions in one sitting or hybrid procedures timely close to each other, multiple aneurysms can be treated technically and timely separated. Previously, open surgery was the only opportunity to intervene, which was associated with significant surgical trauma and was not suitable for high risk patients when devastating complications were likely. Recently combination of lower risk surgery with endovascular treatment options - the so called hybrid techniques - resulted in that indications for treatment remarkably widened. In addition, permanent technical progress made available pure endovascuar solutions, so a wide range of surgical procedures provide number of options for treatment. In this paper we report on the treatment options of complex aortic aneurysms, and present our own relevant experience.

Keywords: complex aortic aneurysms, open surgery, hybrid techniques, endovascular solutions

Beérkezett: 2020. december 22.; elfogadva: 2021. január 28.

\section{Bevezetés}

A complex aortaaneurysmák fogalma az egyszerre több, összefüggő aortaszegmentumra terjedő tágulatot és/vagy a belőlük eredő létfontosságú mellékágakat vagy azok szájadékait is magában foglaló elváltozásokat jelöli. Kettős vagy többszörös aneurysma esetén egymástól anatómiailag jól elválasztható aneurysmákról beszélünk. ${ }^{1}$ Míg a complex aneurysmák egy ülésben vagy időben egymáshoz közeli „hybrid” ellátást tesznek szükségessé, a másik megjelenési forma egymástól időben és technikailag is jól elválasztható beavatkozásokkal oldható meg.

A korábban gyakorolt nyitott beavatkozások nagy sebészi traumával, széles feltárással jártak, esetenként keringést pótló/támogató eljárások és bonyolult szerv-

@ Levelezési cím/Corr. address: Prof. dr. Dzsinich Csaba, MH Egészségügyi Központ, 1134 Budapest, Róbert K. krt. 44., Tel.: +36 309318 906, E-mail: csaba@dzsinich.com 
protektív megoldások alkalmazását tették szükségessé. Ezek a mütétek a folyamatos technikai fejlődés ellenére jelentős szövődményekkel és magas mortalitással jártak. ${ }^{2}$ A magas kockázat az operabilitás feltételeit jelentősen beszúkítette. A mintegy két évtizede az endograftok megjelenése, a hybrid és tisztán endovascularis megoldások bevezetése jelentősen csökkentette a sebészi terhelést, és kiterjesztette a sebészi javallatot olyan betegekre is, akik a magas kockázat miatt korábban nem kerülhettek ellátásra. $^{3}$

\section{A complex aneurysmák típusai}

A complex aortaaneurysmák számos megjelenési formája ismert.

1. Az aorta ascendens aneurysmája/dissectiója coronaria és/vagy aortabillentyü betegséggel társuló változatai:

1.a. az aorta ascendens és a proximalis aortaívre terjedő formációk

1.b. az aorta ascendenst és a teljes aortaívet érintő elváltozások

1.c. az aorta ascendenstől az aorta descendensre terjedő elváltozások

1.d. az aorta ascendensről a teljes distalis aortára terjedő, a thoracalis-thoracoabdominalis-abdominalis és esetleg a bifurcatio alatti területet is érintő aneurysmák

2. Az aortaiv teljes szakaszát involváló elváltozások:

2.a. az aortaívről a thoracalis aortára terjedő aneurysmák/ dissectiók

2.b. az aortaív és a thoracoabdominalis aorta együttes elváltozásai

2.c. az aortaívet érintő és a teljes thoracoabdominalis (iliacalis) aneurysmák

3. Thoracoabdominalis aneurysmák/dissectiók:

3.a. aorta descendens aneurysmák, amelyek a distalis aortaívre is terjednek, és annak kirekesztését és thoracolaparotomiát tesznek szükségessé

3.b. thoracoabdominalis aneurysmák/dissectiók, amelyek a zsigeri és renalis artériák szájadékait is involválják, és akár hasi és medencei artériákra is kiterjednek

4. Hasi aortaaneurysmák, amelyek az aorta zsigeri szegmentumát is érintik:

4.a. az aorta zsigeri és abdominalis szegmentumára terjedő elváltozások

4.b. Az aorta zsigeri szegmentumára és a medencei artériákra terjedő aneurysmák

5. Subrenalis hasi aortaaneurysmák, amelyek az iliacalis és az ilifemoralis területet is érintik

Jelen munkánkban a thoracalis és thoracoabdominalis aortaszakaszt érintő krónikus elváltozásokkal foglalkozunk.

\section{Patológiai háttér}

Az aneurysmák kialakulásának hátterében leggyakrabban egy degeneratív folyamat, az arteriosclerosis áll, amit az aorta rugalmas vázát alkotó elemeinek, elsősorban metallo-proteinázok által okozott fokozatos leépülése okoz. ${ }^{4,5}$ Ritkábban congenitalis érfalgyengeség, mint Marfan-, Ehlers-Danlos-, Loeys-Dietz- stb. szindróma képezi alapját. Ezek hereditaer, kromoszómadefectus miatt alakulnak ki. Az aortafal elasztikus és kollagén rostjainak deficienciája miatt hajlamosítanak normál vérnyomás viszonyok mellett is érfali tágulat - aneurysma és dissectio - kialakulására, nemritkán fiatalabb életkorban is. ${ }^{6,7}$

Az elváltozások klinikailag sokáig némák maradhatnak. Diagnózisuk az esetek egy részében véletlenszerü - más okból végzett képalkotó diagnosztika mellékleleteként kerülnek felismerésre. Mivel morfológiai megjelenésúk igen változatos, az érintett érszakaszoktól függően igen tarka klinikai kórképekkel találkozhatunk. A coronaria és/vagy billentyü betegséggel társuló formák cardialis panaszokat, a supraaorticus ágak érintettsége felső végtagi, cerebrovascularis, vertebrobasilaris tüneteket okozhatnak. A térfoglaló folyamat az aneurysma növekedésével a szomszédos szerveken tracheobronchialis, nyelöcső, sőt szívüregi kompressziót okozhat. Nyelési és légzési zavar, stridoros légzés és cardialis panaszok, szívritmuszavar, mellkasi fájdalom jelentkezhet. Usurálhatja a csontos mellkasfalat és a gerinccsigolyák állományát, neurális fájdalmat okozva. A distalis aortaív tágulata a n.recurrens vongálása folytán rekedtséggel, köhögéssel járhat.

A szerteágazó tünetek diagnosztikájának bázisát a néha szegényes klinikai kép mellett a képalkotó technikák adják. A mellkasfelvétel a középárnyék kiszélesedésével, az aortafal natív mészárnyéka gyanújelként támpontot nyújt a CTA-, MRA-vizsgálatok elvégzéséhez, amelyek részletes morfológiai információt adnak az aorta betegségének lokalizációjáról, kiterjedéséről, a lumen viszonyokról és méretekről. ${ }^{8}$ A klinikai gyakorlatban az $50-55 \mathrm{~mm}$-es és az azt meghaladó átmérőjủ elváltozás exponenciálisan fokozódó rupturaveszély miatt sebészi javallatot jelent. ${ }^{9-11}$

A kivizsgálás további feladata a rizikótényezők felderítése, a beteg teherbíró képességének, azaz operabilitásának megítélése A morfológiai viszonyok pontos komputeres analízise alapján dönthetünk nyitott, hybrid vagy endovascularis megoldásról, a megfelelő méretủ érprotézis, stent graft kiválasztásáról. Utóbbi kiválasztásánál az aorta méreteinek systolo-diastolés változásai is szerepet játszhatnak.

A complex aneurysmák nyitott mütétei az érintett érszakaszoktól függően szükségessé teszik keringéspótló és szervprotektív eljárások bevetését.

Nyitott thoracalis és thoracoabdominalis mütétek során alkalmazott keringéspótló/protectív eljárások:

a. cardiopulmonaris bypass, mély hypothermia, szívmegállítás

b. cardiopulmonaris bypass, moderált hypothermia, selectiv cerebralis perfusio és hütés 
c. cardiopulmonaris bypass, moderált hypothermia, selectiv szervhütés (vesék, zsigerek)

d. atrio-femoralis bal szivfél bypass - egykörös rotációs pumpa artériás vérrel

e. aorto-aorticus vagy subclavio-aorticus időleges bypass saját szívmüködés (Gott-shunt) biztosítja az átáramlást

f. moderalt hypotonia, „clamp-and-go” technika (gyógyszeres keringésjavítás, liquor drainage)

\section{Mütéti megoldások}

1.a. Az aorta ascendens aneurysma coronaria és/vagy aortabillentyü betegséggel társuló változatai cardiopulmonalis bypass, cardioplegia, szisztémás heparinizáció és moderált vagy mély hypothermia alkalmazásával oldhatók meg. Az aorta ascendens pótlása megfelelö méretű érprotézissel végzendő, amelybe a coronariaszájadékok vagy áthidalások beültetése és az aortabillentyü pótlása szükséges. E mütétekhez billentyüvel gyárilag egybeépített protézisek is alkalmazhatók. ${ }^{12}$ Billentyü- megtartásos mütétek esetében a coronariaszájadékok beültetése vagy azok megtartása szükséges (Bentall-, Yacoub-, Tirone David-technikák) (1-3. ábra). ${ }^{12-15}$ Egyes estekben TAVI (transfemoralis, transapicalis, transcarotidealis aortabillentyü-pótlás) után relatíve ép annulus fibrosus és ép Valsalva tasakok és coronariaszájadékok esetében, ha az aorta ascendensen megfelelő rögzítési zóna áll rendelkezésre, stentgraft-implantáció mérlegelendő („Endobentall” procedure).

1.b. Ép aortabillentyü és ép coronariarendszer mellett a proximalis aortaívre terjedő aneurysmák a fenti technikák bevetése mellett az a. anonyma, illetve a. anonyma és bal a. carotis communis időleges kirekesztése miatt az érintett supraaorticus ágak szelektív direkt vagy axillaris, esetleg carotis communis canulatiója nélkülözhetetlen extracorporalis keringés, femoro-femoralis bypass létesítése mellett. Az aneurysma megoldása ún. inlay technikával történik, ami az aneurysmazsák megnyitása után lumenen belüli graftbeépítést jelent. A distalis anastomosis ferde profiljába a fenti ágak szájadéka beültetésre kerülhet. Ha az aneurysma az

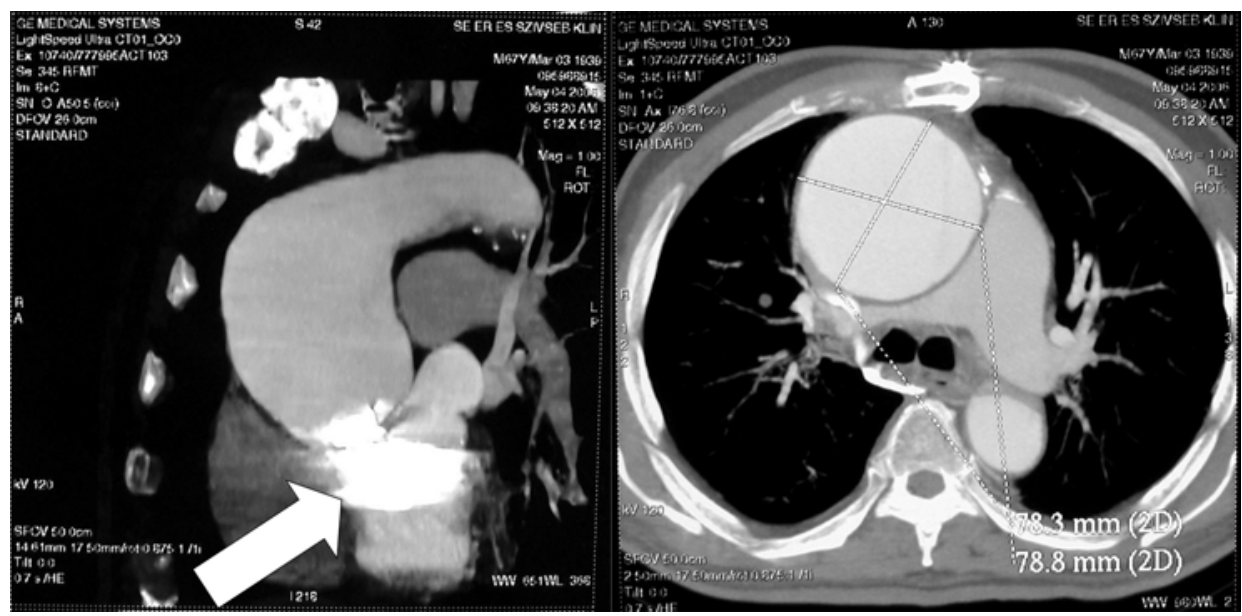

1. ábra. Aorta ascendens aneurysma CT-képe. A tágulat átmérője $75 \mathrm{~mm}$. A bal oldali képen jól látszik az aortabillentyű elégtelensége
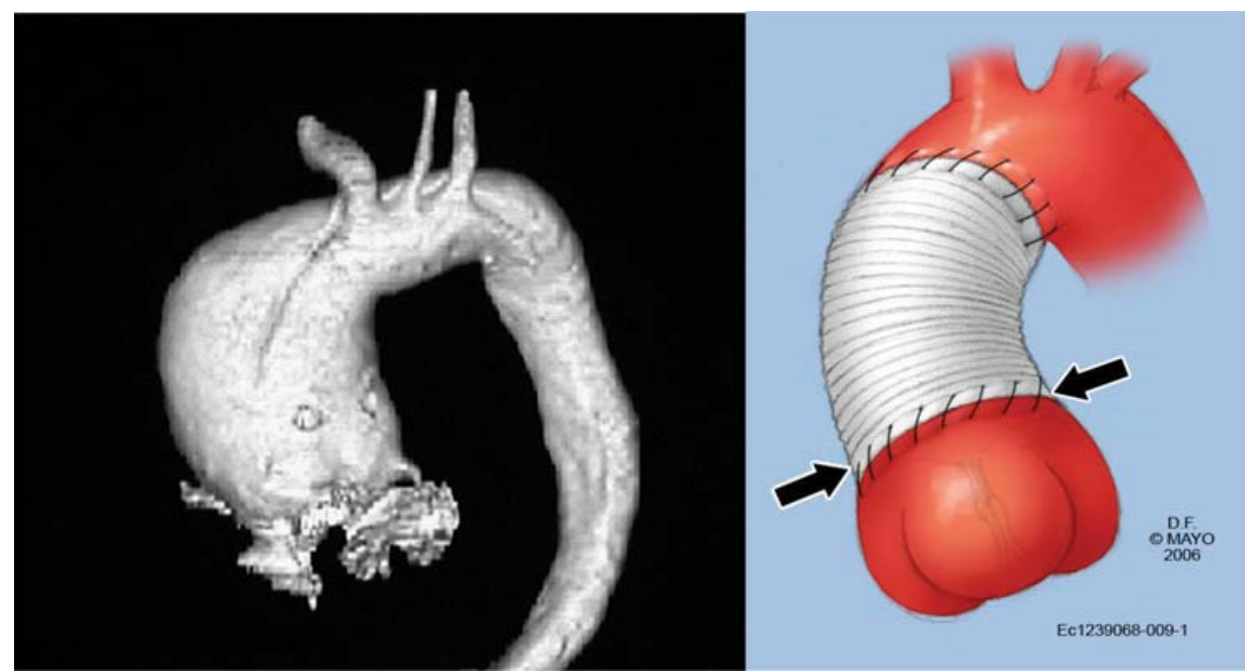

2. ábra. Aorta ascendens aneurysma CT-képe. Az aorta ascendens pótlás vázlata graftinterpositióval 


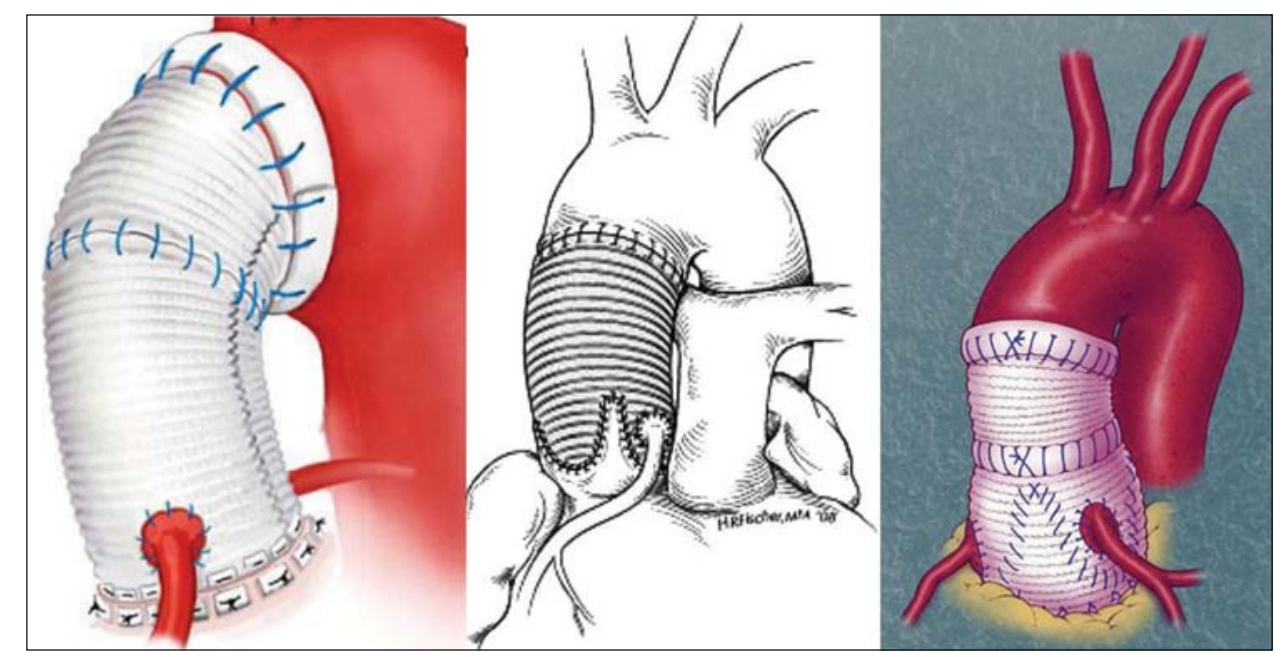

3. ábra. A sémás rajzok az aorta ascendens pótlását mutatják balról jobbra: Bentall-DeBono-billentyüpótlással, Yacoub- és Tirone David-billentyűmegtartással végzett mütéti megoldások vázlata

említett supraaorticus ágakra is ráterjed, vagy azok obliteratív betegsége kíséri, akkor elágazó graftokkal azok rekonstrukciója szükséges. Ezek in situ is kialakíthatók, vagy gyárilag készített változatok alkalmazhatók. Az 1.a. és 1.b. típusú elváltozások megoldása a szívsebészeti mütétek közé, míg a distalisabb elhelyezkedésü változatok többnyire az érsebészet müködési körébe tartoznak.

1.c. A teljes aortaívre terjedő aneurysmák mütéteinek technikai követelményei az előzőekhez hasonlók. Az elváltozás median sternotomiát, mély hypothermiát, és/vagy szelektív cranialis hütés alkalmazását is szükségessé teszi. Az érpótlást általában inlay technikával végezzük. A supraaorticus ágak beültetése történhet a grafton képzett ablakba vagy elágazó grafttal, multiplex oldalággal rendelkező ún. Thoraflex ${ }^{\circledR}$ grafttal. Különleges, manapság alig használt módszer a Heberer-féle „Umwandlungstechnik” ${ }^{16}$ E mütétnél az aorta ascendens és a proximalis aorta descendens között - az aneurysmától proximalisan és distalisan - oldalkirekesztésben megtartott direkt keringés mellett legalább 14-16 mm átmérőjü protézissel hidat alakítunk ki, majd arról előre elkészített oldalágakkal a proximalis anastomosis elkészülte után lépésenként, elágazó grafttal állítjuk helyre a supraaorticus ágakat. Miután az új, mesterséges aortaív elkészült, az eredeti aorta lumenét az aneurysmától proximalisan és distalisan elzárjuk (4. ábra). Szükség esetén a tágulatot megnyitva, annak thrombus bennékét eltávolítva a környezet compressióját jelentősen csökkenthetjük.

Manapság hybrid megoldásként az ép aorta ascendensről oldalkirekesztésben indított elágazó grafttal végzett „debranching”, és megfelelö rögzítési „landing” zóna kialakítása után transfemoralis behatolásból az aortaív tágulatát endografttal fedhetjük le - jelentősen csökkentve a sebészi

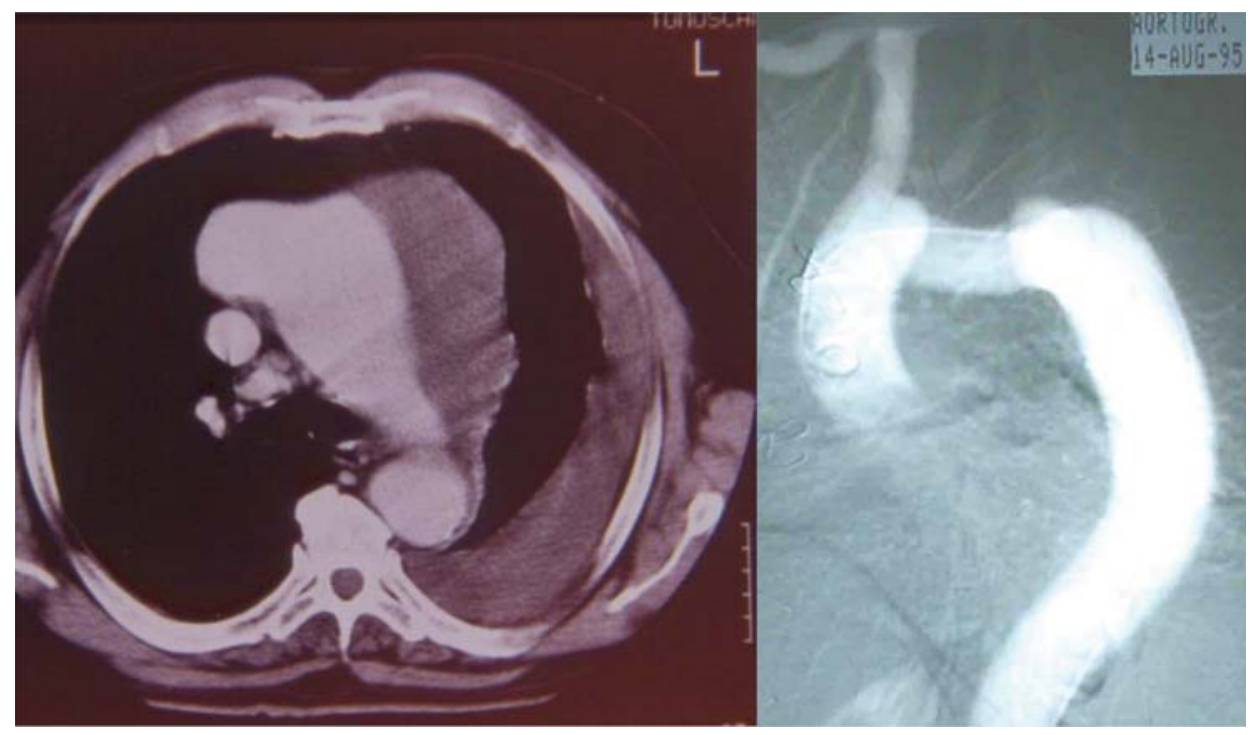

4. ábra. Aortaív symptomaticus tartott ruptura állapotában lévő hatalmas aneurysma CT-képe. Jól látható a mellkasi folyadékgyülem a bal sinusban. A jobb képen a Heberer-féle megoldás („Umwandlungstechnik”) után készült DSA felvétel látható 


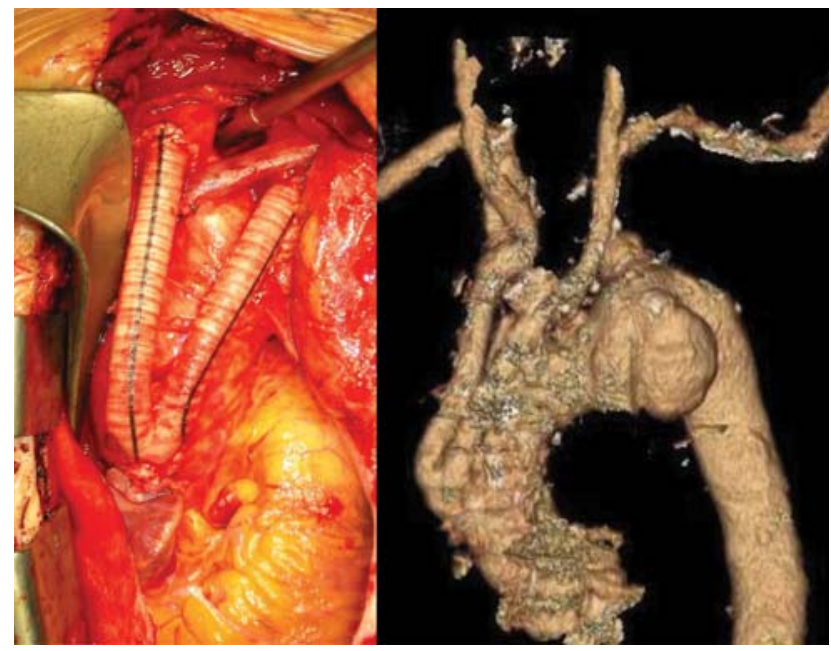

5. ábra. Nyitott thoracoabdominalis aneurysma műtéte után a complex aortaív-aneurysma miatt aorto-bicaroticus bypasst és bal subclavio-caroticus transzpozíciót végeztünk. A kép bal oldalán az aorto-bicaroticus bypass mütéti képe látható. A bal oldalon az ívaneurysma 3D-s CT-képét mutatjuk

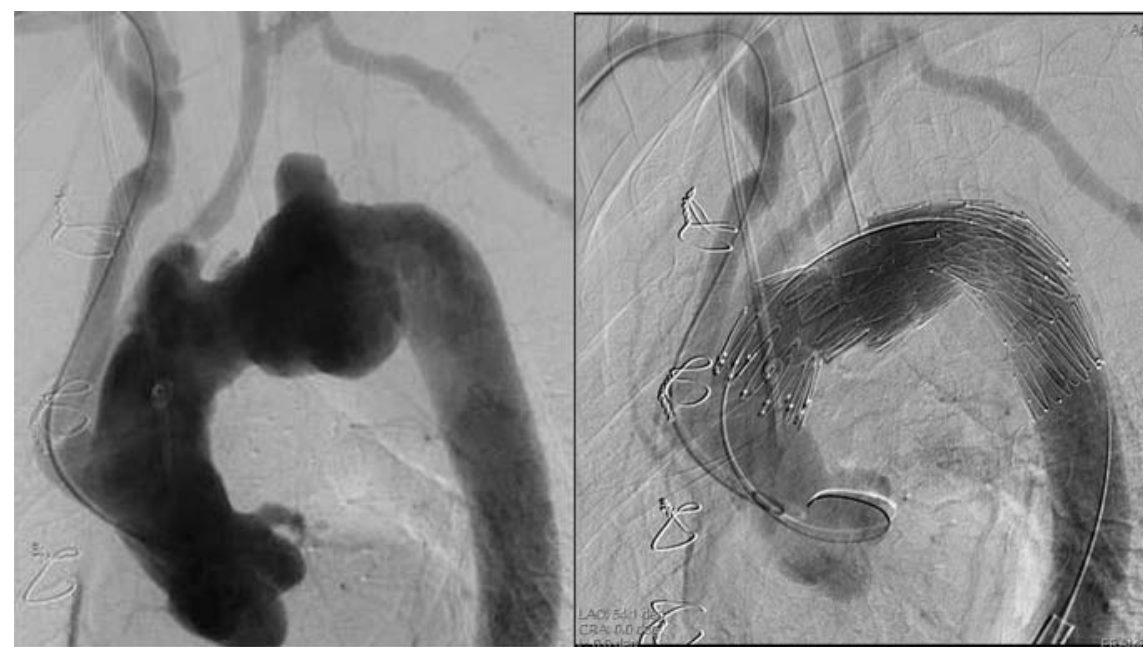

6. ábra. A bal oldalon az 5. ábrán bemutatott eset stentgraft-behelyezése elötti DSA-képe, majd a kép jobb oldalán az implantáció után készült DSA-felvétel látható

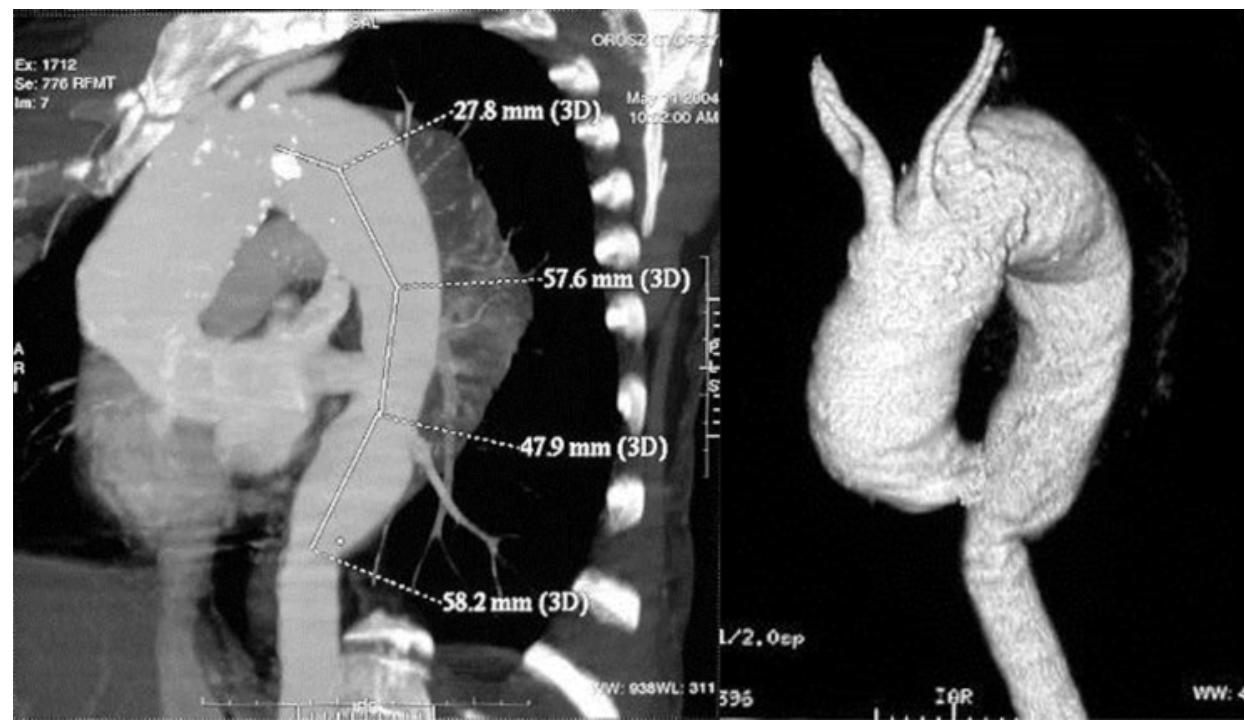

7. ábra. Complex aorta ascendens ív és descendens aneurysma CT-képe látható a bal oldalon. A kép jobb oldalán az elváltozás 3D-s CT-képe 


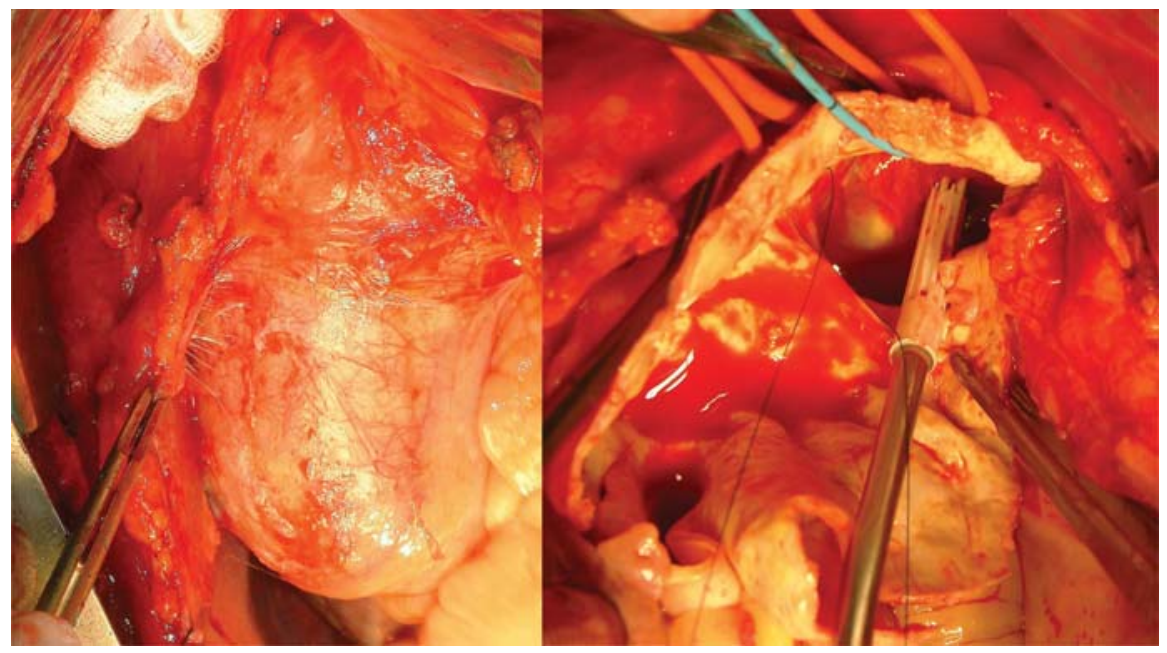

8. ábra. A 7. ábrán bemutatott complex aortaaneurysma centralis szakaszát mutatja median sternotomia és az elváltozás megnyitása után. Intraoperatív felvételek

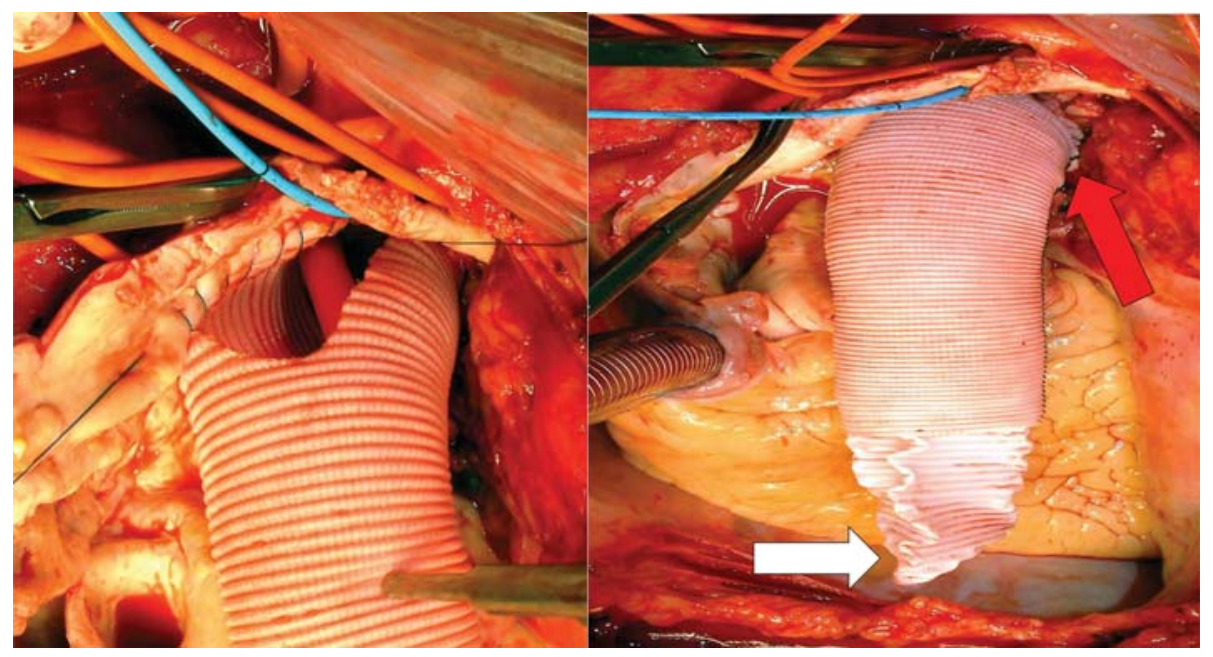

9. ábra. A 7. ábrán bemutatott elváltozás intraoperatív képei. Bal oldalon: a protézis „,ablakába” ültettük be a supraaorticus ágak szájadékait. A kép jobb oldalán a piros nyíl mutatja az a. subclavia alatti rögzítő varratsort, a fehér nyíl a graftba invaginált protézisszakaszt mutatja, amit elefántormányként az aorta descendensbe tolunk előre

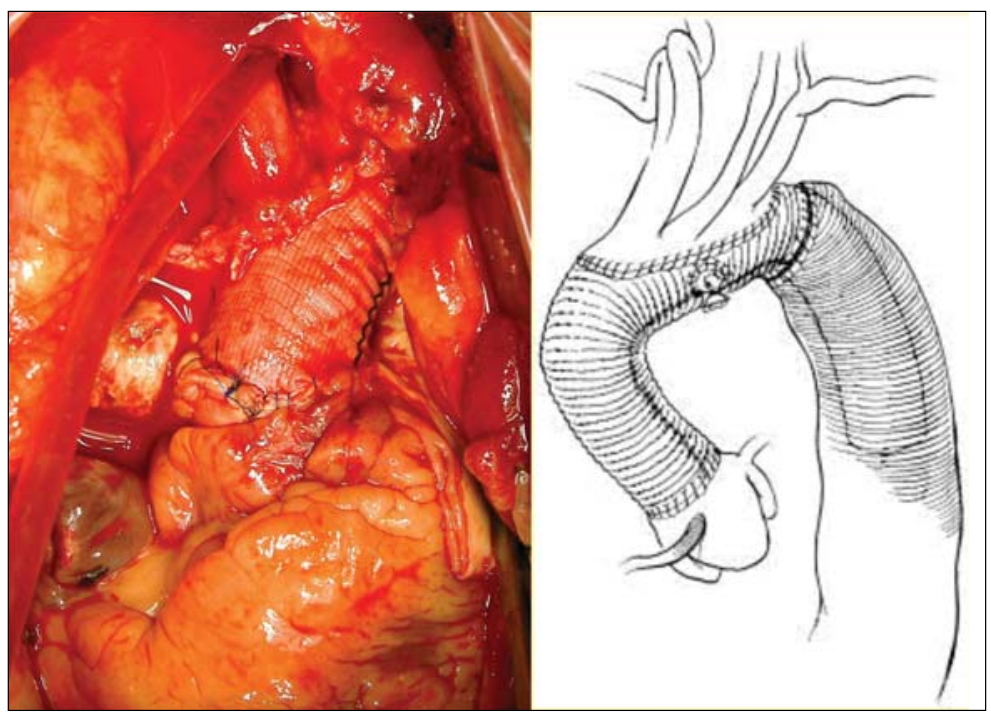

10. ábra. Az előző ábrákon bemutatott mütét az inlay aortapótlás centrális szakaszát mutatja. A jobb oldali rajz a posztoperatív állapot sémás ábrázolása 


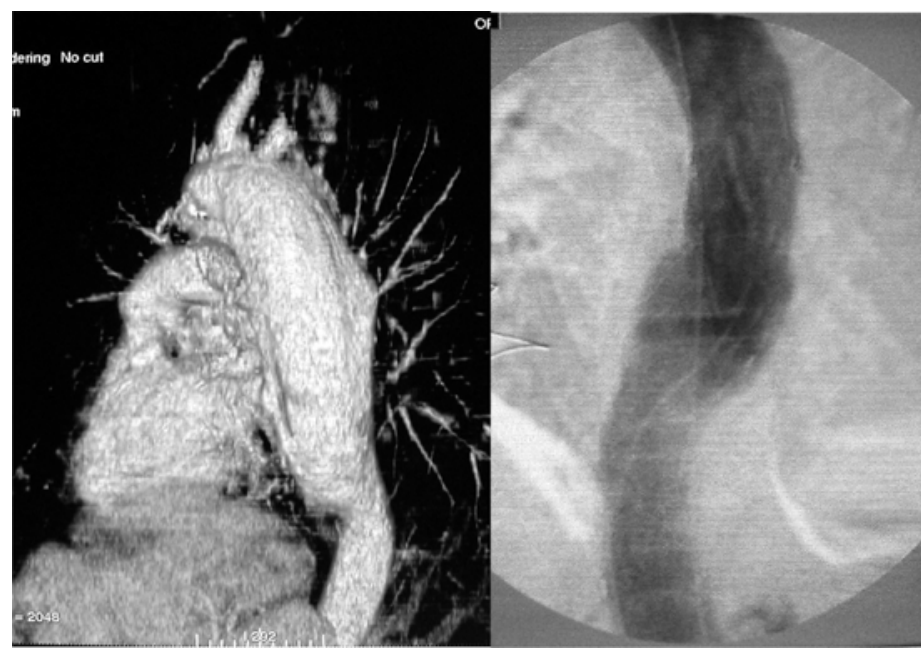

11. ábra. Az előző mütét utáni bal oldali CT-képen jól felismerhető az aorta descendensbe szabadon benyúló „elephant trunk” protézis. A kép jobb oldalán a distalis aorta descendensben stentgrafttal kiegészített rekonstrukció DSA-képe látható

terhelést (5., 6. ábra). A ,debranching” az aorta nagy mellékágainak sebészi áthelyezését jelenti, amit endograft rögzítésre alkalmas aortaszakasz kialakítása érdekében végzünk. ${ }^{17}$

Teljes endograftmegoldások, fenestralt és oldalágakkal ellátott vagy paralel graftok beépítésével végzett technikák újabb lehetőséget teremtettek e terület kezelésben. ${ }^{18-21}$

1. A teljes aorta ascendenst, aortaívet és a thoracalis aortát magába foglaló aneurysmák esetén hybrid eljárásként az 1.b. nyitott mütétet végezzük. Az aortaív distalis pontján a graftot direkt vagy a gallérral ellátott graftot a bal a. subclavia szájadék alatt körkörös varrattal fixáljuk. Ezt követően a protézis hosszabb, distalis szakaszát invagináljuk az aneurysma descendensbe terjedő szakaszába. E szabadon, az aortába lógó elefántormányt (,elephant trunk") második ülésben transfemoralisan bevezetett endografttal egészítjük ki 22,23 (7-11. ábra).

2. A distalis aortaívtől kezdődő és a zsigeri aortaszegmentumra is terjedő aneurysmákat Crawford négy csoportba sorolta, amit Safi egy ötödik változattal, a zsigeri-suprarenalis szakasz aneurysmáival egészített ki (12. ábra).

\section{Crawford-osztályozás (12. ábra):}

I. Közvetlenül a bal a. subclavia szájadékánál kezdődő elváltozás, ami csak az aorta descendensre terjed.

II. A teljes thoracoabdominalis, az aorta bifurcatióig érő aneurysmák.

III. Az aorta descendens aneurysmái, amelyek túlnyomóan a rekesz felett helyezkednek el.

IV. Az aorta descendens distalis szakaszáról induló, esetenként az aorta bifurcatióig terjedő tágulatok. ${ }^{24}$

V. A Safi által javasolt rekesz alatti, zsigeri ereket involváló tágulatok. $^{25}$

Mütéti megoldások a thoraco-abdominalis aneurysmák esetében:

Bár a nyitott mütéteket általában inlay technikával végezzük, azaz a megnyitott aneurysma lumenén belül építjük

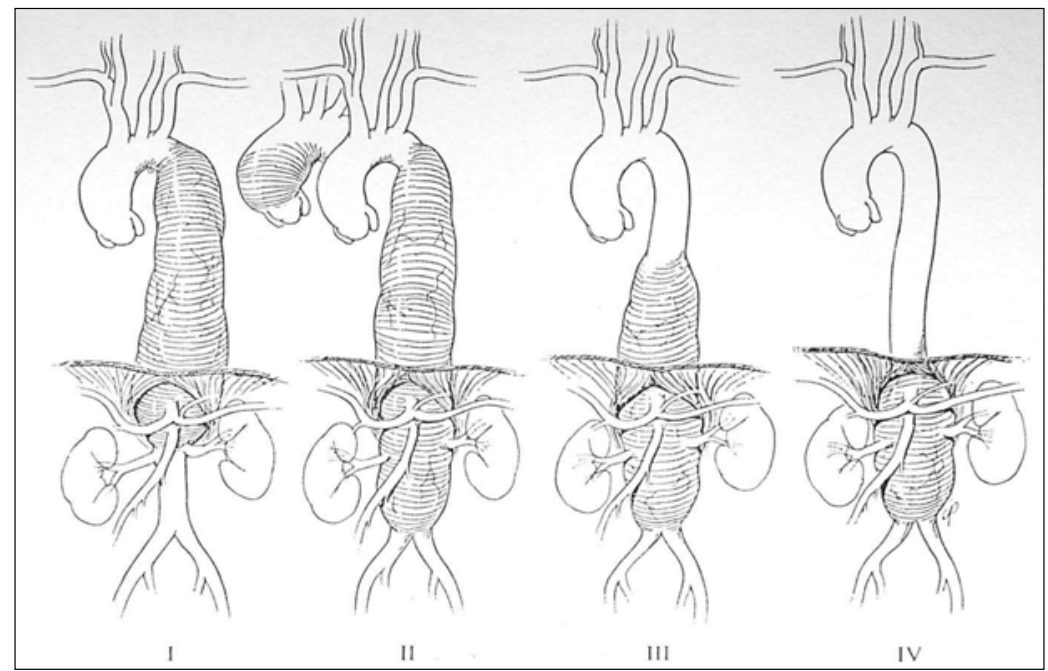

12. ábra. A thoracoabdominalis aortaaneurysmák osztályozása Crawford szerint 


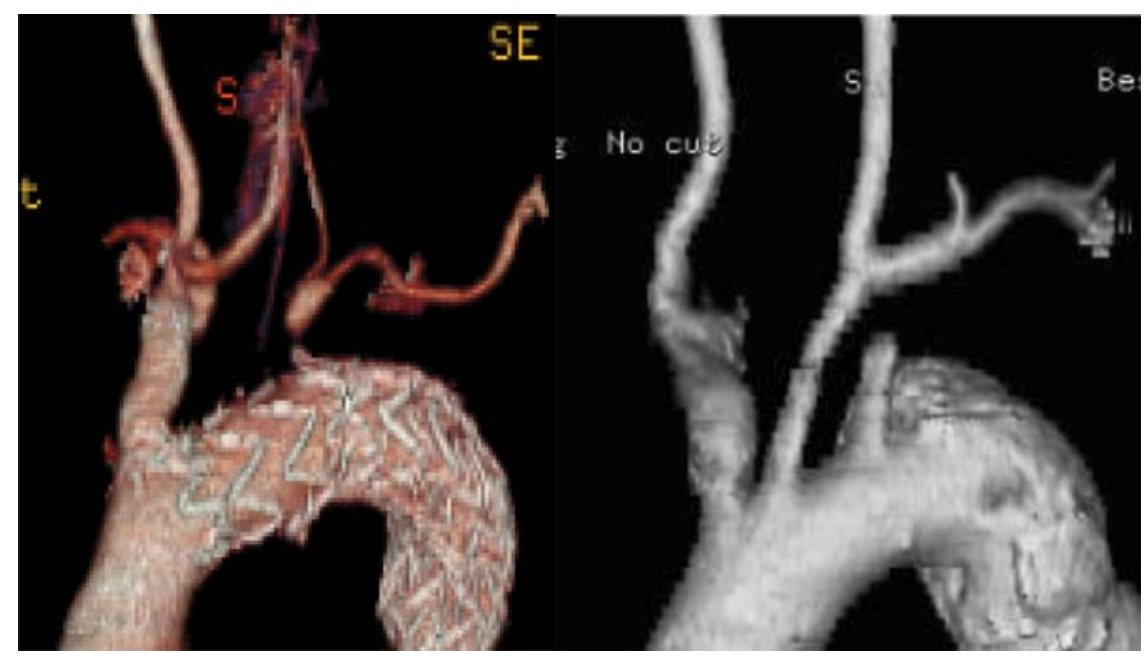

13. ábra. A kép bal oldalán intercaroticus bypass, a jobb oldalon subclavio-caroticus transzpozíció képe látható

be a graftot (Crawford), aorto-aorticus, oldalágakkal kombinált bypass technika is ismert (DeBakey), amelynél az aneurysmát megkerülve hidaljuk át azt.

A Crawford I. aneurysmák nyitott mütétei egyes eseteiben intercaroticus bypass és/vagy a bal a. subclavia a bal a. carotis communisba történő transzpozíciójával kell azok átáramlását biztosítanunk (13. ábra). Ez a distalis debranching a stent graft-beültetés rögzítési zónájának kialakításához szükséges előzetes sebészi beavatkozás. Manapság kagyló (,scallop”) profilú stent grafttal, paralel grafttal, („Chimney” és „,snorkel”) ezt a sebészi előkészítést kiválthatjuk.

A nyitott mütét stabil jobb oldalfekvésben a 6 . bordaközben végzendő thoracotomia után a bal a. subclavia eredésétől - ritkábban a bal a. carotis communis eredésétől proximalisan aortakirekesztést tesz szükségessé. Az anaes- thesia részéről a heparinisatio, liquor drainage, electrophysiologiai és/vagy liquor biochemiai monitorizálás, a cardiac afterload kezelése, szeparált tüdő ventilláció biztosítása szükséges. Gyógyszeres keringésjavítás és/vagy mesterséges distalis perfusio biztosítása (lásd fentebb) a gerincvelöi keringés növelése és az ischemiás károsodás kivédése érdekében nélkülözhetetlen. Az inlay technika alkalmazása során törekednünk kell a collateralis spinalis keringés minél magasabb szintü megtartására a kirekesztés időtartama alatt, ezért lehetőleg lépésenként, rövid aortaszakaszok kirekesztésére törekszünk. A nyitott spinalis artériaszájadékok megőrzése érdekében ferde profilú anastomisisok képzését ajánlom. Amennyiben diagnosztikai munkánk során a domináns spinalis artériák preoperatíve azonosíthatók, azokat a grafton képzett „ablakba” beültetjük (14. ábra). Intraoperatíve a megnyitott aorta lumene felől dominánsnak ítél-

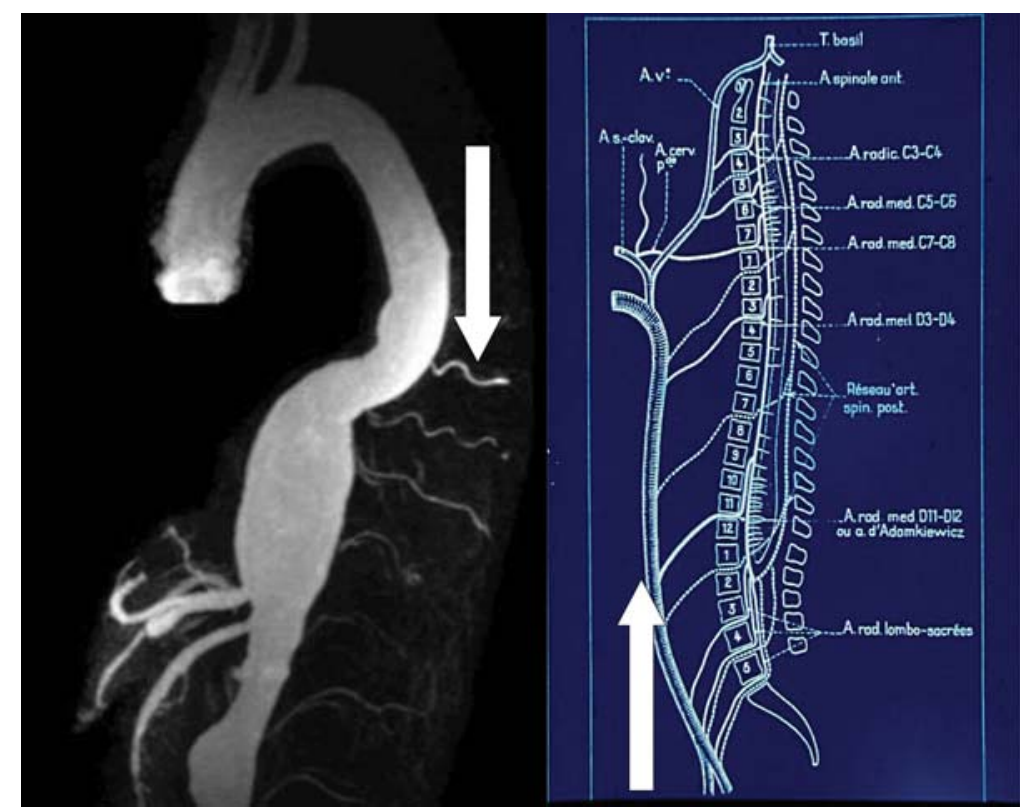

14. ábra. Thoracoabdominalis aortaaneurysma MRA-képe. Nyíl jelzi a domináns spinalis artériát. A jobb oldali képen a spinalis vérellátást mutató rajzon ugyancsak nyíl jelzi az a. radicularis magnát (Adamkiewitz) 


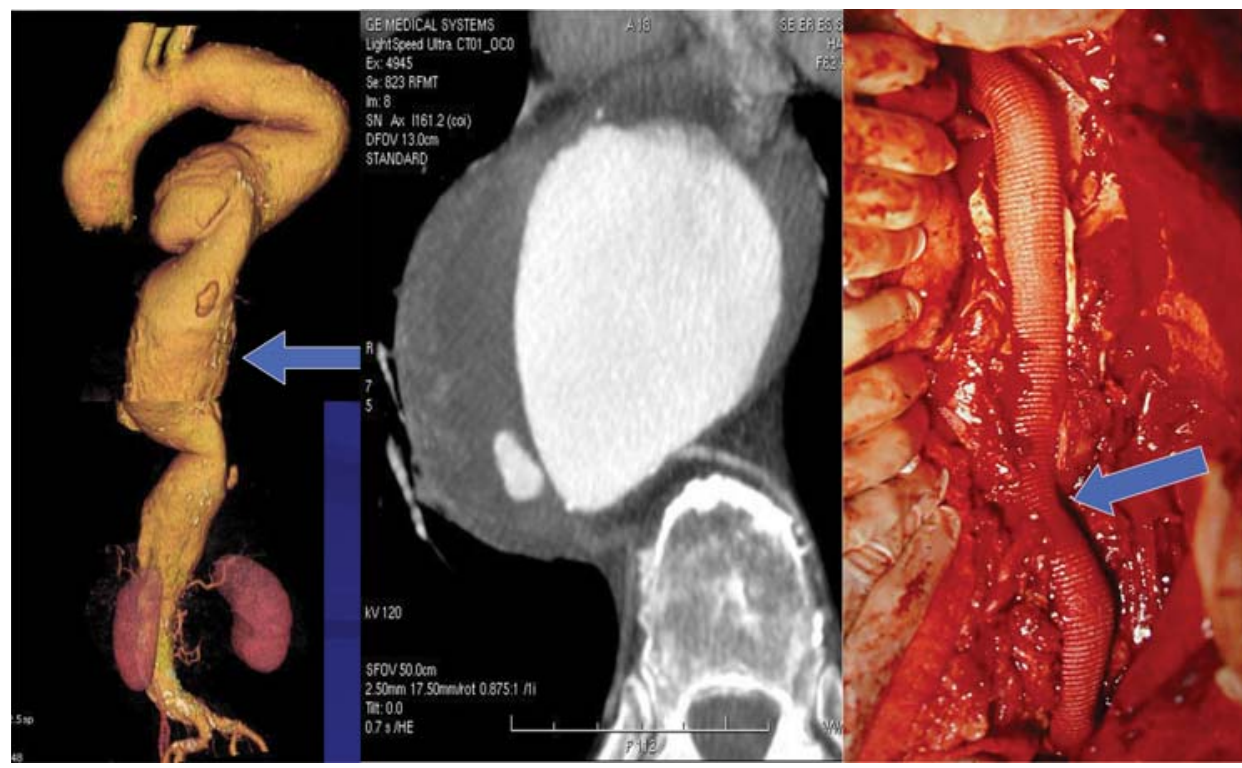

15. ábra. Crawford II. típusú aortaaneurysma 3D-s CTA-képét és maximális haránt átmérőjét mutatja. A kép jobb oldalán a mellkasi és hasi aorta inlay pótlása látható, amelyen a nyíl jelzi a graft ablakába ültetett zsigeri ágak, és a szeparált bal a. renalis replantatio helyét

hető spinalis artériák hasonló módon beültetésre javasoltak. E plusz anastomosis(ok) a kirekesztési időt kritikus mértékben megnyújthatják, amit elektrofiziológiai vagy biokémiai monitorizálási módszereink jelezhetnek. Ilyen esetekben a distalis perfúzió növelése, hütés, gyógyszeres gerincvelö-védelem szükséges. Egyes esetekben a rekonstrukciót célszerü a distalis anastomosissal kezdeni, ami proximalis keringés megtartásával segíti a magasabb szintü collateralis keringés fenntartását.

A Crawford II. a thoracoabdominalis aorta teljes hoszszára kiterjedő aneurysmák esetén vagy az axillától a spina iliaca superiorig terjedő thoracolaparotomiát vagy kettős, a 4. bordaközben thoracalis és distalis thoracoabdominalis feltárást kell végeznünk. A nyitott mütétek nagy sebészi terheléssel és megnyúlt mütéti idővel és magasabb szövődményaránnyal járnak (15., 16. ábra). Nyitott mütétnél proximalis anastomosis elkészítése, illetve endograft implantációja elött/alatt a distalis aortaíven a korábban vázolt debranching beavatkozásokat kell elvégeznünk proximalis „landing zóna” megteremtése céljából. Ebben a típusban a visceralis és renalis ágak keringésének biztosítására ezen aortaszakasz anatómiájának sebészi átépítése is szükséges-

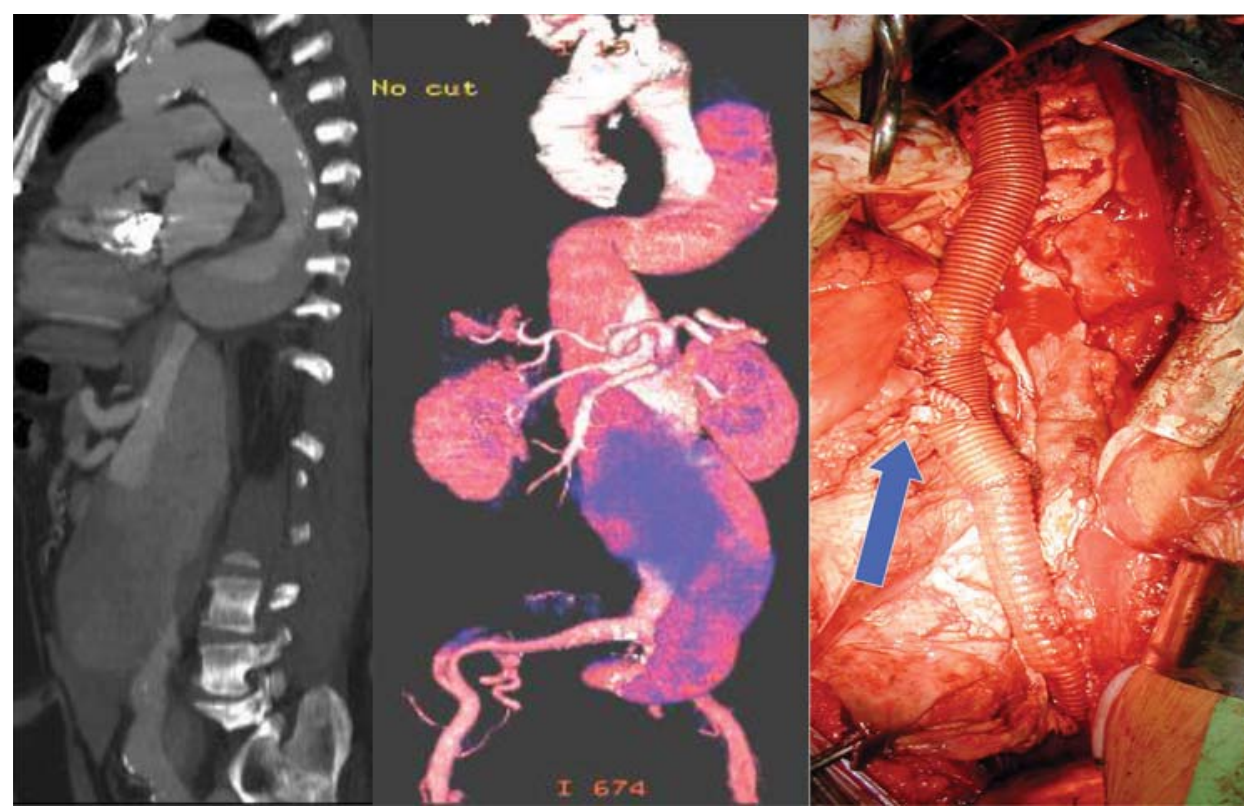

16. ábra. Chronicus dissectio után kialakult hatalmas thoracoabdominalis aortaaneurysma, ami a bal a. ilica communisra is ráterjedt. CTA és 3D-s rekonstrukció a bal és a középső képen látható. Jobb oldalon intraoperatív felvétel. A bal a. subclaviától distalisan bifurcatiós grafttal kiegészített inlay aortapótlás képe, amelyben Gore-tex ${ }^{\circledR}$ graftinterpositummal állítottuk helyre az a. mesenterica superior és a bal a. renalis keringését (nyíl) 


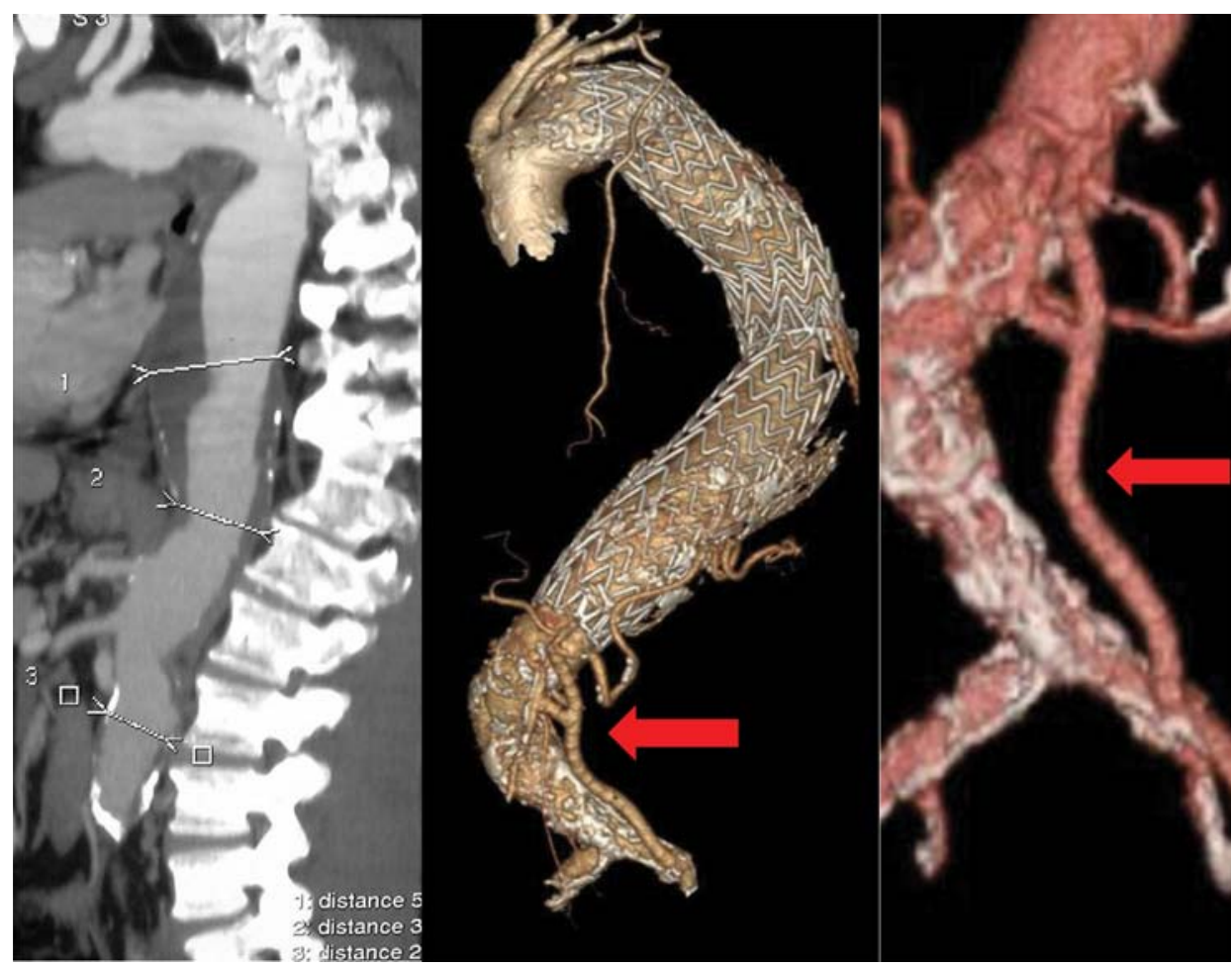

17. ábra. Crawford III. aortaaneurysma. Az aneurysma mellkasi és felső abdominalis szakaszát stent grafttal fedtük le. A zsigeri keringést a bal a. iliaca communisról indított elágazó grafttal, distalis debranching megoldással állítottuk helyre (nyilak)

sé válhat retrográd debranching útján (17. ábra). Legújabban a fenestralt graftok, illetve paralel graftok alkalmazása ezt a sebészi előkészítést feleslegessé teheti.

A Crawford III., IV. és $V$. típusú elváltozások nyitott mütéttel ugyancsak thoracolaparotomia útján közelíthetők meg a legjobban. A truncus coeliacus, a. mesenterica superior és a jobb artéria renalis általában ferde profilú anastomosisba belefoglalhatók. A bal a. renalis rekonstrukciója néha csak graft interpositummal oldható meg (17. ábra). Ezekben az esetekben a megnyúlt kirekesztési idő miatt bal a. renalis szeparált perfúziója jeges Ringer-laktáttal a vese védelme, ischemia türöképesség idejének kiterjesztése érdekében szükséges. A medencei artériákra terjedő aneurysma bifurcatiós graft beültetését indokolja. Ezen morfológiai változatok tisztán endovascularis megoldása a fentebb vázolt technikákkal is lehetséges - és a szakmai fejlödés ebbe az irányba mutat és a nyitott mütétek arányát egyre inkább csökkenti.

\section{Összefoglalás}

A complex aortaaneurysmák kezelése a szív és érsebészet legnagyobb kihívásai közé tartozik. Megoldásukhoz széles körü anatómiai, patológiai, keringésfiziológiai és szervspecifikus ismeretek mellett több szakma együttmüködésére van szükség. A hagyományos sebésztechnikai ismeretek és a gyorsan változó eszközös feltételek nyomon követése és alkalmazása teszi lehetővé a mütéti terhelés csökkentését, a javallat kiszélesítését, és az eredmények javulását. E súlyos kórképek ellátása a látványos fejlődés ellenére még nem tekinthető lezárt folyamatnak, és a hybid vagy teljes endovascularis megoldások térhódításának vagyunk tanúi. Mindazonáltal a hagyományos nyitott mütétek ismerete extrém morfológiai elváltozások esetében, és stentgraftbeültetések szövődményeinek ellátása miatt továbbra sem nélkülözhető.

\section{Irodalomjegyzék}

${ }^{1}$ Johnston $K W$, Rutherford RB, Tilson MD, Shah DM, Hollier L, Stanley JC: Suggested standards for reporting on arterial aneurysms. Subcommittee on Reporting Standards for Arterial Aneurysms, Ad Hoc Committee on Reporting Standards, Society for Vascular Surgery and North American Chapter, International Society for Cardiovascular Surgery. J Vasc Surg 1991; 13: 452-458.

${ }^{2}$ Coselli JS, LeMaire SA, Preventza O, de la Cruz KI et al.: Outcomes of 3309 thoracoabdominal aortic aneurysm repairs. J Thorac Cardiovasc Surg 2016; 151: 1323-1337.

${ }^{3}$ Oderich GS, Tallarita T, Kalra M, Duncan AA, Gloviczki P, Vrtiska T, Cha S, Bower TC: Contemporary results of open complex abdominal aortic aneurysm repair using a standardized classification for comparison with fenestrated endografts. J Vasc Surg 2011; 53: 27S-8.

${ }^{4}$ Tromp G, Kuivaniemi H, Hinterseher I, Carey DJ: Developments in genomics to improve understanding, diagnosis and management of aneurysms and peripheral artery disease. Eur J Vasc Endovasc Surg 2009; 38(6): $676-682$. 
${ }^{5}$ Ruddy JM, Jones JA, Ikonomidis JS: Pathophysiology of thoracic aortic aneurysm (TAA): is it not one uniform aorta? Role of embryologic origin. Progress in cardiovascular diseases 2013; 56(1): 68-73.

${ }^{6}$ Isselbacher EM, Lino Cardenas CL, Lindsay ME: Hereditary Influence in Thoracic Aortic Aneurysm and Dissection. Circulation 2016; 133: 2516-2528.

7 Pomianowski P, Elefteriades J: The genetics and genomics of thoracic aortic disease. Ann Cardiothorac Surg 2013; 2: 271-279.

${ }^{8}$ Green DB, Palumbo MC, Lau C: Imaging of Thoracoabdominal Aortic Aneurysms. J Thorac Imaging 2018; 33(6): 358-365.

${ }^{9}$ von Allmen RS, Anjum A, Powell JT: Incidence of descending aortic pathology and evaluation of the impact of thoracic endovascular aortic repair: a population-based study in England and Wales from 1999 to 2010. Eur J Vasc Endovasc Surg 2013; 45: 154-159.

${ }^{10}$ Isselbacher EM: Thoracic and abdominal aortic aneurysms. Circulation 2005; 111: 816-828.

11 Diehm N, Dick F, Schaffner T, Nicolas Diehm, Schmidli J et al.: Novel insight into the pathobiology of abdominal aortic aneurysm and potential future treatment concepts. Prog Cardiovasc Dis 2007; 50: 209-217.

${ }^{12}$ Bentall H, De Bono A: A technique for complete replacement of the ascending aorta. Thorax 1968; 23(4): 338-339.

${ }^{13}$ Yacoub M, Klieverik L, Melina G, Edwards S, Sarathchandra P, Bogers A, Squarcia U, Sani G, van Herwerden $L$, Takkenberg J: An evaluation of the Ross operation in adults. J Heart Valve Dis 2006; 15(4): 531-539.

${ }^{14}$ Ross D: Homograft replacement of the aortic valve. Lancet $1962 ; 2(7254): 487$.

${ }^{15}$ David TE, Feindel CM: An aortic valve-sparing operation for patients with aortic incompetence and aneurysm of the ascending aorta. J Thorac Cardiovasc Surg 1992; 103: 617-621.
${ }^{16}$ Heberer GR, Löhr GHH: Aneurysmen, in Aorta und große Arterien. Georg Thieme Verlag, Stuttgart-New York, 1966; 47-49.

${ }^{17}$ Dzsinich Cs, Vaszily M, Vallus G, Dzsinich $M$ et al.: „Debranching” - új érsebészeti feladat az aortaív és a thoracoabdominalis aorta hibrid mütétei számára. Magy Seb 2014; 67(6): 353-361.

18 Silverberg D, Rimon U, Raskin D, BarDayan A, Halak $M$ : Parallel stent grafts for the treatment of complex aortic aneurysms: A single center study. Vascular 2018; 26(5): 490-497.

${ }^{19}$ Haulon S, Amiot S, Magnan PE et al.: An analysis of the French multicentre experience of fenestrated aortic endografts: medium-term outcomes. Ann Surg 2010; 251: 357-362.

${ }^{20}$ Oderich GS, Ricotta JJ: Modified fenestrated stent grafts: device design, modifications, implantation and current applications. Perspect Vasc Surg Endovasc Ther 2009; 21(3): 157-167.

${ }^{21}$ Entz L, Nemes B, Zoltán Szeberin $Z$ et al.: Fenesztrált stent-graft beültetés Magyarországon. Magy Seb 2015; 68(3): 88-93.

${ }^{22}$ Borst HG, Walterbusch $G$, Schaps D: Extensive aortic replacement using "elephant trunk" prosthesis. Thorac Cardiovasc Surg 1983; 31(1): 37-40.

${ }^{23}$ Ius F, Hagl Ch, Haverich A, Pichlmaier M: Elephant trunk procedure 27 years after Borst: what remains and what is new? European Journal of Cardio-Thoracic Surgery $2011 ; 40(1): 1-12$.

24 Crawford ES: Thoraco-abdominal and abdominal aortic aneurysms involving renal, superior mesenteric, celiac arteries. Ann Surg 1974; 179: 763-772.

25 Safi HJ, Miller CC: Spinal cord protection in descending thoracic and thoracoabdominal aortic repair. Ann Thorac Surg 1999; 67: 1937-1939.

A cikk a Creative Commons Attribution 4.0 International License (https://creativecommons.org/licenses/by/4.0/) feltételei szerint publikált Open Access közlemény, melynek szellemében a cikk bármilyen médiumban szabadon felhasználható, megosztható és újraközölhetö, feltéve, hogy az eredeti szerző és a közlés helye, illetve a CC License linkje és az esetlegesen végrehajtott módosítások feltüntetésre kerülnek. (SID_1) 